INSIGHTS INTO REGIONAL DEVELOPMENT

ISSN 2669-0195 (online) http://jssidoi.org/IRD/

2021 Volume 3 Number 3 (September)

http://doi.org/10.9770/IRD.2021.3.3(1)
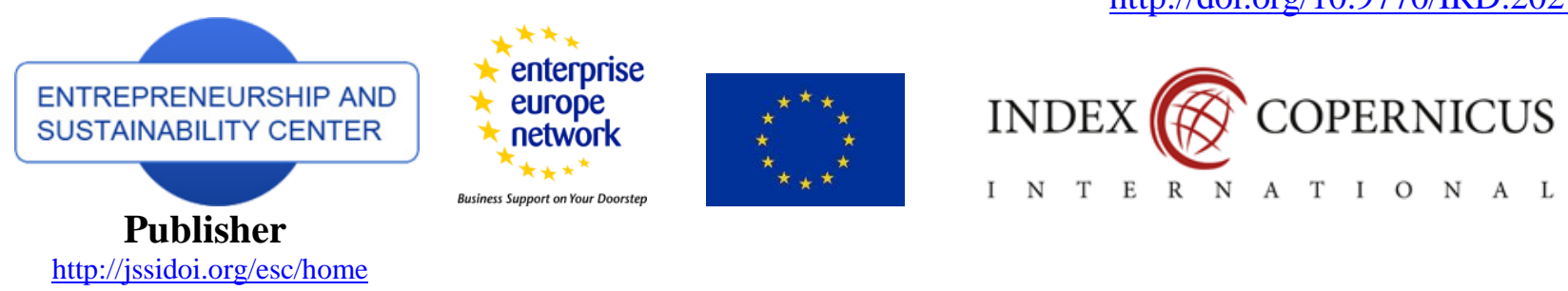

$\begin{array}{llllllllllllll}\text { I } & \mathrm{N} & \mathrm{T} & \mathrm{E} & \mathrm{R} & \mathrm{N} & \mathrm{A} & \mathrm{T} & \mathrm{I} & \mathrm{O} & \mathrm{N} & \mathrm{A} & \mathrm{L}\end{array}$

http://jssidoi.org/esc/home

\title{
CIRCULAR SOLAR INDUSTRY SUPPLY CHAIN THROUGH PRODUCT TECHNOLOGICAL DESIGN CHANGES*
}

\section{Tadas Radavičius ${ }^{1,5}$, Arvid van der Heide ${ }^{2}$, Wolfram Palitzsch ${ }^{3}$, Tom Rommens ${ }^{4}$, Julius Denafas ${ }^{5}$, Manuela Tvaronavičiene ${ }^{6}$}

\author{
${ }^{1 * 6}$ Department of Business Technologies and Entrepreneurship, Faculty of Business Management, Vilnius \\ Gediminas Technical University, Vilnius, Lithuania \\ ${ }^{2}$ PV Department, IMEC, EnergyVille II Campus, Thor Park 8320, 3600 Genk, Belgium \\ ${ }^{3}$ LuxChemtech GmbH, Alfred Lange Str. 18, 09599 Freiberg, Germany \\ ${ }^{4}$ Sustainable Materials department, VITO, Mol, Belgium \\ ${ }^{5}$ Soli Tek R\&D JSC, Mokslininku str. 6A, Vilnius, 08412 Lithuania \\ ${ }^{5,6}$ Kaunas University of Technology, K. Donelaičio g. 73, Kaunas, 44249 Lithuania
}

E-mails: ${ }^{*}$ tadas.radavicius@vilniustech.lt (Corresponding author)

Received 15 May 2021; accepted 27 July 2021; published 30 September 2021

\begin{abstract}
Climate change forces countries and organisations to transition towards renewable energies (RE). The transition requires a substantial amount of renewable energy installations, such as PV (photovoltaic) systems. EU solar cells (main PV panels component) manufacturing capacity in 2019 were only $0,2 \%$ compared to the world producers' capacity. It makes the European Union energy transition dependable on the foreign countries. In addition, the supply chain of the solar industry is facing issues of silicon solar panels having critical raw material (CRM) silver and toxic materials such as lead. The solar panels themselves are a complex combination of components making recovery of the materials a difficult process $(\mathrm{Ha}, 2020)$. These and further issues of the lack of circularity in the solar value chain endangers reliable access to solar energy in the long term. The goal of this research is to increase the circularity in the industry by designing technologically the product in a circular way. In order to achieve this goal, the authors blended information provided in the contemporary scientific literature with the shared expertise of producers and other stakeholders. Insights about the possible technological design changes of the solar panels, their issues, and their impact on the supply chain were gathered through an online workshop and EU Horizon 2020
\end{abstract}

\footnotetext{
* The authors acknowledge the valuable contribution of all project partners within CIRCUSOL (call: H2020-EU.3.5.4). This project has received funding from the European Union's Horizon 2020 research and innovation programme under grant agreement 776680 .
}
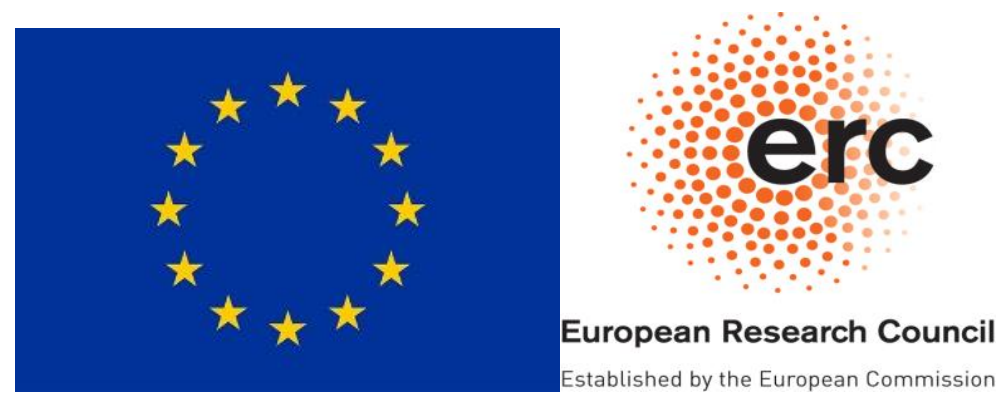


\section{INSIGHTS INTO REGIONAL DEVELOPMENT}

ISSN 2669-0195 (online) http://jssidoi.org/jesi/

2021 Volume 3 Number 3 (September)

http://doi.org/10.9770/IRD.2021.3.3(1)

project CIRCUSOL. As a result of the research, the authors proposed product circularity improvement' steps and specific technological solutions, which would allow enhancing circular solar industry supply chain. The proposed technological solutions are radio-frequency identification (RFID), lead-free ribbons with bismuth as lead replacement, an electrically conductive adhesive (ECA), new industrial cell encapsulation (N.I.C.E), and fluorine-free back sheet.

Keywords: circular supply chain; the solar industry; circular economy; product circular technological design

Reference to this paper should be made as follows: Radavičius, T., van der Heide, A., Palitzsch, W., Rommens, T., Denafas, J., Tvaronavičienè, M. 2021. Circular solar industry supply chain through product technological design changes. Insights into Regional Development, 3(3), 10-30. http://doi.org/10.9770/IRD.2021.3.3(1)

JEL Classifications: O14, O32

\section{Introduction}

To ensure ever-lasting access to renewable energies such as wind, solar, hydro, etc., their supply chains must be sustainable. Usage of limited raw materials to produce equipment for energy generation could be arguably the opposite of the idea of having renewable energy if the resources to produce the systems are limited or/and are poorly managed. This research is focusing on the solar industry which is the fastest growing renewable energy (RE) source in the world (IEA, 2020). Typical PV systems consist of solar panels, inverters, mounting systems, and cables. Solar panels are the product that allows the collection of solar irradiation and converting it to electricity. The solar panel consists of solar cells that are directly responsible for electricity generation (Fraunhofer, 2020). The solar panel itself is a tightly structured lamination consisting of glasses, back sheets, lamination material, aluminum frames, and adhesives. The materials combination can change depending on the panel technological design, but the structure is always based on tightly sealed protection for solar cells. For this reason, it is very difficult to recover materials back from the solar panels. Although the lifetime of silicon-based (95\% of the market) solar panels can be as much as 30 years and more they still contain critical raw materials, toxic materials, and precious materials such as silver, high-grade silicon, lead, and solar-grade glass. It is crucial to improve the circular processes in the supply chain to maintain the resources instead of leaving solar panels in landfills or degrading their materials value during end-of-life (EoL) treatment.

Objectives of the research are:

To analyse literature related to the circular supply chain.

To develop a simple process to identify main product circularity issues and steps to improve the circularity of the product.

To apply process steps for product circularity improvement of solar panels.

To evaluate the scalability of the technological design changes.

The article analyses the issues and potential technological design changes of the solar panel in order to find design changes solutions that could allow higher circularity. Joint work performed by the authors that represent different solar industry areas of expertise allows evaluating and rating design changes based on circular strategies.

\section{Supply chains for the circular economy: literature review}

Maranesi and Giovanni (2020) discuss that the Circular Economy (CE) can be utilised to reduce raw materials usage. It can be facilitated through upgradable and long-lasting products, using renewable resources for products, and ensuring that the materials go through recycling and upcycling. Authors also suggest that downcycling could be used to retrieve the materials although it implies the loss of materials value. Kopnina (2018) who base their thinking on the cradle-to-cradle approach thinks that the downcycle (downgrade of the materials) should be avoided. To ensure materials in the closed-loop system the upcycling (high-value recycling) needs to be ensured because "recycling" as it is practiced now usually involves loss of material quality (Singh et al. 2019). Cannella et 


\section{INSIGHTS INTO REGIONAL DEVELOPMENT}

ISSN 2669-0195 (online) http://jssidoi.org/jesi/

2021 Volume 3 Number 3 (September)

http://doi.org/10.9770/IRD.2021.3.3(1)

al (2021) demonstrate the closed-loop supply chain (CLSC) method, which is part of CE goals to keep the materials in the closed-loop. It allows saving costs for the processes of re-manufacturing goods based on authors scenario models through mathematical equations.

Various barriers slow down the transition to a circular supply chain. Kumar et al (2021) suggest that the main barriers for circularity in the supply chain are the risk of miss investment, lack of waste management, poor resource quality, insufficient market demand, lack of awareness of industry 4.0, and so forth. The authors map the barriers with the circular economy theories, such as cradle-to-cradle, industrial ecology, biomimicry, and blue economy. These theories include methods that can allow circularity, such as resource circularity, cost-saving through product quality, decreasing emission, waste reduction \& pollution, process design for resource and energy efficiency, and so forth. Govindan and Hasanagic (2018) conducted a literature review on circular economy from a supply chain perspective to identify economic drivers, barriers, and practices. The author's five proposed clusters of drivers are:

Policy and economy. This is reflected through the need for economic growth and the establishment of procedures for product take-back systems via policies.

Health. Cluster refers to the increase of health for the public and animals that CE can deliver compared to linear economy.

Environmental protection. It includes climate change, agriculture, and renewable resources.

Society. Indicates job creation, consumer awareness, and urbanization.

Product development. Increasing the efficiency of materials and the energy and the value of the products.

Product development that results in additional value creation can incentivise companies to innovate through circularity that leads to value created along the supply chain.

To understand the processes of resource recovery from the CE perspective Iacovidou et al (2020) suggest that various stages of resource are involved: from production and consumption to end-of-life (EoL) management with each of them having its sub-systems. The proposed system allows grasping opportunities and understanding barriers towards CE implementation. Two out of five levels in the paragraphs below "Technologies, infrastructure and innovation" and "Activities performed by business and the market" demonstrate for organizations how to increase $\mathrm{CE}$ in their supply chain with their actions:

Technologies, infrastructure, and innovation level. Materials, components, and products (MCP) degradation happens during the usage, disposal, and recycling phases. For these reasons supply chain never can be entirely circular (Iacovidou et al. 2020). Infrastructure and innovations are needed to ensure a lower degree of materials degradation. The current issues in this level are (Iacovidou et al. 2020):

o Low amount of repair, remanufacturing, and reuse activities due to lack of supply and demand networks linked with second-hand components and/or products.

o Rare cases of designing MCPs by taking into account EoL and CE considerations (repair, longevity, recycling, re-manufacturing, etc.).

o Lack of traceability of components and products taking into account their characteristics, and performance inside the value chain.

Low supply of second-hand components and products, low consideration in products and components design while taking into account CE principles, and lack of traceability are issues and opportunities at the same time. Product circular design can allow a closed material loop as well as contribution in the future to the supply of second-hand components and materials (Acerbi \& Taisch, 2020). In the end, it can create workplaces and additional revenues for the organisations. Everything can be enhanced by traceability to access object history, improve distribution, map locations, etc., as is the case with plastics EoL management (Mackay, 2020). Traceability can be accessed with various technologies such as radio frequency identification (RFID) tags, 3D scanning lasers, optical character recognition, building information modeling (BIM), sensors networks, blockchain technology, etc. (Iacovidou et al. 2020). 


\section{INSIGHTS INTO REGIONAL DEVELOPMENT}

ISSN 2669-0195 (online) http://jssidoi.org/jesi/

2021 Volume 3 Number 3 (September)

http://doi.org/10.9770/IRD.2021.3.3(1)

Activities performed by businesses and the market. In terms of $\mathrm{CE}$ for business operations, one of the decisions organizations can make is to use secondary resources. This is a challenge due to unpredictable market conditions of the secondary materials (Eurostat, 2020). Secondary resource markets have high fragmentation due to the type of materials and their material grade (quality) and a varying amount of them being salvaged which usually do not match demand and vice versa (Bris, 2016; Iacovidou et al. 2020). Companies enforcing their processes with circular business models (CBM) allow the creation of a take-back system of the components and/or products to ensure better management towards re-manufacturing, recycling, re-use, etc. (Geissdoerfer et al. 2020). At the same time, it can extend a product's lifetime, usage, and allow the introduction of a product-service system for the customers (Geissdoerfer et al. 2020). Evaluation of business possible changes to product circularity is important to choose the best alternative. Alamerew et al (2020) proposed a multi-criteria evaluation process to select the best fitting circular strategy at the product level. It is used to compare business as usual (BAU) and potential circular strategies on criteria such as economic, social, technical, business impacts. To make the product more circular it is important to understand the potential impacts of those changes towards further supply chain via circular strategies (recycle, re-use, repair, etc.).

The eco-design approach allows improving the product's environmental impact (European Commission, 2019). Eco-design allows redesigning the product, its concept, materials, and packaging for higher circularity impact. The process involves evaluating the product to understand what changes it should have to make it more recyclable, re-usable, less toxic, reduce negative environmental impact, etc. It can allow to reduce costs, introduce new products in the market, improve quality, etc. (Sanyé-Mengual et al. 2014). The eco-design process includes quantifying the impact through LCA (life cycle analysis) which can be time-consuming and costly for SMEs. It can require feasibility assessment (technical, social, economic) and quantitative assessment (LCA, product carbon footprint). After assessments company can conduct a selection process for available strategies (evaluating the strategies based on low-medium-high priority) to make the product more environmentally friendly (SanyéMengual et al. 2014). Table 1 shows the main barriers and weaknesses of the eco-design approach tools.

Table 1. Barriers and weaknesses of the tools used in the Eco-design process

\begin{tabular}{|c|l|l|l|}
\hline Tools & Definition & Barriers & Weakness \\
\hline LCA & $\begin{array}{l}\text { Calculation of products environmental } \\
\text { impact. }\end{array}$ & $\begin{array}{l}\text { The required high amount of } \\
\text { time and specific knowledge. }\end{array}$ & $\begin{array}{l}\text { Requires a large amount of } \\
\text { data (usually sensitive) from } \\
\text { the supply chain and strong } \\
\text { cooperation. }\end{array}$ \\
\hline Simplified LCA & $\begin{array}{l}\text { Calculation of simplified environmental } \\
\text { impact of product/services without having } \\
\text { complete data on the product. }\end{array}$ & $\begin{array}{l}\text { Specific knowledge and costs The need for training to use } \\
\text { associated with time and tools } \\
\text { for calculating environmental } \\
\text { impact. }\end{array}$ & $\begin{array}{l}\text { Theols and simplification can } \\
\text { lead to strategy selection } \\
\text { based on the not correct } \\
\text { interpretation. }\end{array}$ \\
\hline $\begin{array}{l}\text { Designing for „, } \\
\text { approach }\end{array}$ & $\begin{array}{l}\text { Specific scope for the approach, such as } \\
\text { design for recycling, disassembly, etc. }\end{array}$ & $\begin{array}{l}\text { The approach relies on staff } \\
\text { experience and expertise. }\end{array}$ & $\begin{array}{l}\text { Need to understand product } \\
\text { criticalities before starting the } \\
\text { analysis. }\end{array}$ \\
\hline
\end{tabular}

Source: adapted from Rossi et al. 2016

While considering industry shift to more circular practices it is important to understand the possible design changes of the products that can improve the re-usability, recycling, etc. Design changes of the product can require high involvement of specific organisations in the supply chain if considering, for example, design with one material (requires the involvement of components suppliers), design for re-usability (companies that are conducting activities related to re-use/repair), design for recycling (recycling companies), etc. Organisations involvement in the designing phase and evaluating the design changes are important when considering the scalability of the design changes that could be implemented by the industry companies. This would as well allow 


\section{INSIGHTS INTO REGIONAL DEVELOPMENT}

ISSN 2669-0195 (online) http://jssidoi.org/jesi/

2021 Volume 3 Number 3 (September)

http://doi.org/10.9770/IRD.2021.3.3(1)

industry SME's to reduce time and costs (sometimes they cannot afford or have no expertise) into the research of the possible design changes if the design changes were evaluated at the industry level.

\section{Methodology}

Based on the literature review synthesis the analysis steps of product circularity improvement are shown in figure 1. The 4 step approach aims to rate possible design changes of the product that could be implemented by the solar industry companies. Technological design changes are understood as the change of product structure that would increase the circularity. This research article considers that the technological design change (or just design change) for circularity differs from product innovation by focusing more on the improvement of circularity rather than increasing efficiency of the product, reliability, features, etc. This consideration of definition allows more space for collaboration as innovations at the product level that improves the product functionality, effectiveness, etc., are heavily protected and safeguarded by companies as intellectual property. The design changes oriented to circularity allow signifying the required collaboration within the supply chain ( 2 or more supply chain organisations) to make design change work at the industry level (re-usability, repairing, recycling, etc.).

Step 1. To investigate CE design issues information will be used from the research articles, data from Solitek company, an online workshop organised within the CIRCUSOL project, information from the EU Horizon 2020 project CIRCUSOL and its partners, and news articles. The literature review allows investigating solar panel design issues. Because of the fast-changing industry, information will be supported by expert's inputs and findings from the CIRCUSOL project, and online workshop.

Step 2. Based on the design issues relevant circular strategies will be analysed. Circular strategies in this research scope consist of 9R: Refuse, Rethink, Reduce, Reuse, Repair, Refurbish, Remanufacture, Repurpose, Recycle, and Recover. 9R is used to connect the design issues with their impacts to specific strategies. This allows narrowing down the strategies that have high relevance to the product for potential circularity improvement.

Step 3. Ratings of the possible design changes will be done based on their impact (low-medium-high) to the relevant circular strategies and economic considerations. The low-Medium-High ratings are done by the authors (experts) that represent $\mathrm{R} \& \mathrm{D}$ in the solar industry, solar panels recycling, solar panels manufacturing, and expertise in the circularity of the solar industry. Possible design changes of the panels were researched through the CIRCUSOL project by conducting a literature review of the newest developments in different designs of the panels. Potential tests of the design changes will be done if there is a lack of understanding about their possible impacts on the product performance (solar panel).

Step 4. Possible design changes will be evaluated through supply availability of materials, components, economic and environmental factors, etc. The quantitative approach will contribute to step 3 qualitative impact evaluation by adding consideration to the scalability of these design changes through different design changes adoption scenarios in the market. 




Fig. 1. Product circularity improvement' steps

Source: made by the authors

The 4 steps approach allows to analyse industry circularity issues, relate them to circular strategies, research possible design changes, and understand their possible impacts and scalability potential. Relating the current design issues and possible changes to circular strategies allow to increase collaboration within the industry which is necessary to achieve a more circular supply chain. Making a visible impact on different actors in the supply chain that is occurring from current design issues through circular strategies can lead to justification for collaboration to investigate design changes that could benefit multiple organisations in the supply chain.

\section{Solar panel circularity}

Silicon-based solar panels will be analysed through this paper as it has the majority of the market share compared to all solar panels technologies ( 95\%). Silicon-based solar panels consist of the following materials: solar cells, glass (tempered), EVA (plastic), back film (plastic), aluminum frame, and back sheet (plastic) (Eco-sources, 2019). Depending on the panel it can have either two glasses or a back sheet instead of the glass in the back. Aluminum frames are also optional for panels. Each solar panel has a junction box attached, which has diodes in them for electricity transferring from the panel. The composition of the typical solar panel is shown in figure 2. 


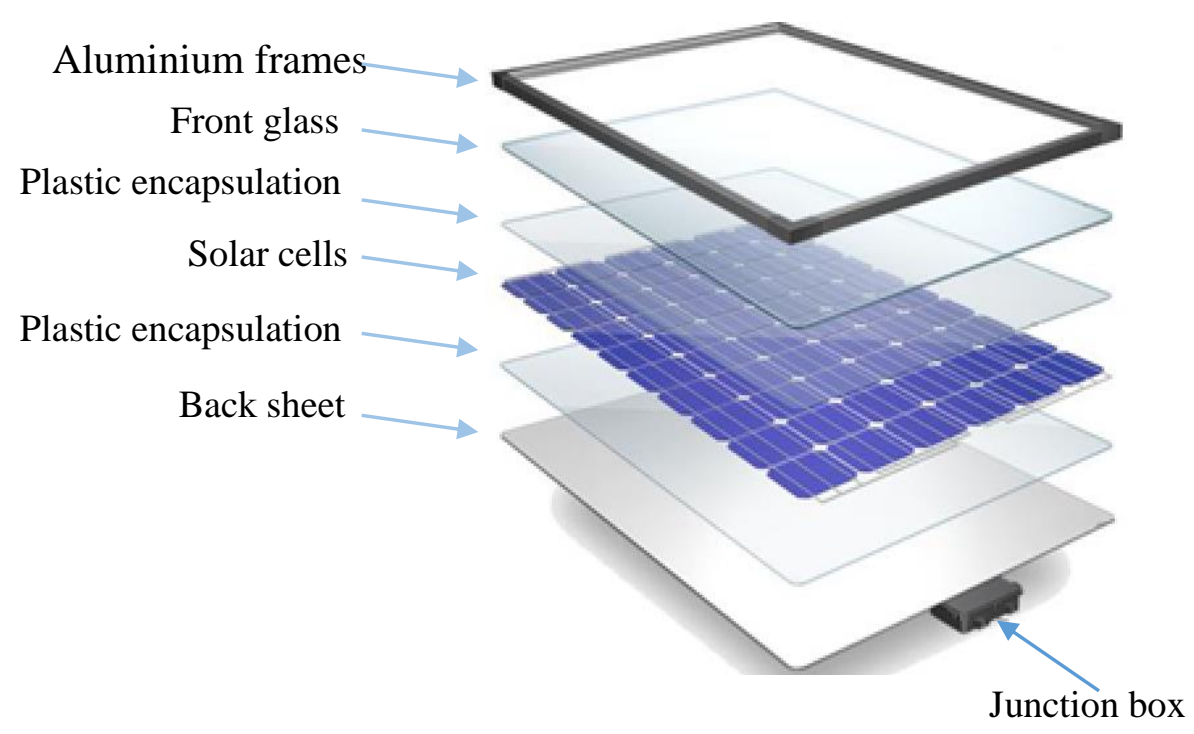

Fig. 2. Solar panel composition

Source: adapted from Svarc, 2020

Front and back glass (can be back sheet) with plastic layers protects the solar cells from the environment. The tightly-sealed structure allows panels to increase the longevity of solar cells but at the same time can hinder repair, reuse, or recycling. In terms of recycling companies such as Veolia, dedicated to the recycling business, can recover $95 \%$ of materials from such panels (Veolia, n.d.).

Silicon-based panels material composition are aluminum ( 17\%), copper $(\sim 1 \%)$, plastic $(\sim 12,8)$, silicon $(\sim 2,9)$, glass $(\sim 65,8$, although depends if its glass-glass or glass-back sheet panel), lead $(<0,1 \%)$ and silver $(<0,1 \%)$ (Cucchiella et al. 2015). Lead and silver have importance for closed-loop material cycling due to toxicity and being the critical raw material. Although silicon material is abundant for solar cell production, the production of solar cells in Europe is only $0,2 \%$ of total world production with China having around $75 \%$ of the market (Luceño-Sánchez et al. 2019; Statista, n.d.). Some glass suppliers state that their products are $100 \%$ recyclable, although it is valid only till the component is assembled to the solar panel. From that moment it is not possible with current recycling technologies to recover the same quality glass suitable for the same purpose due to impurities (Tao et al. 2020). Plastics are usually incinerated for energy generation as they cannot be recycled (D'Adamo et al. 2017; Latunussa et al. 2016).

The review of the structure of solar panel components and the materials shows that it is of high importance to ensure proper handling of the solar panel through its lifetime cycles (production, operation, recycling, etc.). Methods such as the better design of the panel, using renewable materials, or recycled content could allow increasing the circularity. The next step is to identify the design issues of the panel.

\subsection{Design issues limiting circularity}

Solar panel back sheets are laminated with adhesives making re-melting and re-use of recovered materials not suitable for new plastic products (Ha, 2020). The same laminating principle is used while manufacturing panels using encapsulation materials (plastic) that glue silicon cells, back sheets, and glass altogether. Aluminium frames can be removed manually, glass can be shattered and melted again or recovered in-tact if not broken. Polymeric encapsulants and back sheets are usually non-recyclable. Solar panel glass cannot be recycled as float glass due to impurities, such as lead, plastic, and/or cadmium (thin-film panels) (Shellenberger, 2018). Wafer (the main part of solar cell structure) during solar cell production is doped with boron and phosphorous making it challenging 


\section{INSIGHTS INTO REGIONAL DEVELOPMENT}

ISSN 2669-0195 (online) http://jssidoi.org/jesi/

2021 Volume 3 Number 3 (September)

http://doi.org/10.9770/IRD.2021.3.3(1)

during the recycling phase to purify silica. The main problem definition of a solar panel is a multi-layer composition that is connected with adhesives. Separation of each layer, without crushing the panel for high-value material recovery requires change for solar panel design.

To understand more about the technological design issues of the solar panel CIRCUSOL project had organised an online workshop. The online workshop took place in 2020-10-19. There was one representative from each of the following organisations: Solitek (solar panels manufacturer in Lithuania), LuxChemtech (PV panels recycler in Germany), VITO (Belgium), IMEC (Belgium), Bifa (Germany), CEA (France) (R\&D institutes), UDZ-consult (consultant from Germany), and PV Cycle (association of PV panels voluntary take-back and recovery in Europe). Solitek has participated in the EU Horizon2020 projects CABRISS and Eco-Solar that were related to the recycling and production of solar panels from recycled materials. The research institutes have dedicated departments related to the PV industry: PV technologies development, leading PV research projects, etc. The consultant had experience in the PV sector from participation in activities related to PV recycling. PV Cycle has a vast amount of experience as they are responsible for the collection and further management of PV EoL waste in Europe. LuxChemtech in addition to the recycling of solar panels is developing advanced recycling processes for PV panels. Each of the participants contributed with their knowledge and expertise related to the PV industry. It is notable, that due to the lack of additional organisations from the upstream supply chain (materials and components manufacturers) the deeper insights from possible technological design changes of solar panel components were difficult to address. The discussion results of the workshop are below:

Sandwich structure. The sandwich structure of multiple layers challenges recycling companies to create processes for each layer removal. The current dominant recycling process shreds panel resulting in recovering low-quality materials. A presentation about recycling processes being developed around the world by LuxChemtech (solar panels recycling company) showcased that the processes which focus on high-value recycling are still not being used on an industrial scale. The processes which can be classified as high-value recycling are being used at the industrial level only by First Solar (thin-film-based solar panels manufacturer) with their in-house recycling facility.

Strong adhesion between the layers. The encapsulation materials have strong adhesion in-between the glasses/back sheet and encapsulation that surrounds the solar cells. Pyrolysis, a high-energy intensive process, is the main industry-ready recycling process step that allows destroying encapsulation materials as separation of the layers is not possible.

Changing dimensions of the solar panels. With increasing solar cells and panel sizes the overall panel dimensions are increasing making it harder to have an automated recycling line that could process various sized panels.

Strong adhesion of glass-glass panels. There are processes how glass-back sheet panels glass can be recovered (hot-knife, water-jet) in-tact. The same process approach is still being developed for glass-glass panels. Strong adhesion between the layers requires energy-intensive processes to separate the layers.

During the workshop, experts have suggested design changes for the panel to improve recyclability and re-usability of the panels. They are as follows:

Information sharing. Recycling companies could benefit from access to the details about different kinds of panels. The information could be related to material content (in \%), solar panel dimensions, etc.

White-colored front glass gaps between the solar cells. The recycling method is being developed by LuxChemtech that is based on adhesion destruction using light. This recycling concept could potentially allow easier separation of the layers. Whether white-colored gaps or black back sheets have a better impact on the destruction of adhesive using light induction is unclear as experiments are needed.

Fish can solar panel concept. Glass-back sheet panels could have a metal attachment that could be hooked by a machine in the recycling process to "peel of" the back sheet mechanically.

The information-sharing platform that was discussed during the workshop could allow enhancing recycling operations. Mentioned design changes need to be tested but it shows that there is room for discussion from different actors in the supply chain on the topic of how the product design could be changed to enhance 


\section{INSIGHTS INTO REGIONAL DEVELOPMENT}

ISSN 2669-0195 (online) http://jssidoi.org/jesi/

2021 Volume 3 Number 3 (September)

http://doi.org/10.9770/IRD.2021.3.3(1)

circularity in the whole industry. Discussed issues and possible design changes were more linked with improving recycling. From the $\mathrm{CE}$ perspective product should enter (if possible) repair and re-use stages. The following step is to understand design issues impact on the circular strategies.

\subsection{Design issues impact on the relevant circular strategies}

Refusing one of the functions, rethinking the product, or reducing material usage is limited to the functionality of solar panels and can involve technological innovations that would be too sensitive to share know-how or discuss it with other industry companies. The current recycling of solar panels results in the generation of lower grade materials (industrial grade silicon, shattered glass). It is yet not economically efficient to recover all materials due to the complexity of solar panel design. There is re-usability potential of solar panels in different PV system applications which can additionally require repairing or refurbishment. Past few years high growth in panel power (from $300-350 \mathrm{Wp}$ to $500-650 \mathrm{Wp}$ ) mainly due to an increase in solar panels size enables higher re-usability potential as costs per $\mathrm{Wp}$ for refurbishing are decreasing. For longer solar panels usage and shift to second-hand applications repair and refurbishment circular strategies is also important for the industry. Remanufacturing and repurpose strategies have not been identified as relevant for the solar panel based on the findings in the literature and inputs from the experts. The recovery strategy is relevant in the combination with the re-usability strategy where there is a need to produce solar panels with less toxic materials as possible when the second-hand application is done in a country with not yet developed recycling infrastructure.

Each of the design issues impacts differently repairability, reusability, recyclability, and refurbishment strategies. Refurbishment and repair strategies are considered as one for the solar panel due to similarities of the activities and processes. Based on design issues table 2 provides key insights on recycling, reusing, and repairing/refurbishment.

Table 2. Design issues impact on circularity strategies

\begin{tabular}{|c|c|c|c|}
\hline $\begin{array}{l}\text { Current design } \\
\text { issue of the } \\
\text { solar panel }\end{array}$ & Impact on recycling & Impact on re-usability & $\begin{array}{l}\text { Impact on repairing and } \\
\text { refurbishment }\end{array}$ \\
\hline $\begin{array}{l}\text { Sandwich } \\
\text { structure }\end{array}$ & $\begin{array}{l}\text { Requires sophisticated and costly processes to recover high quality } \\
\text { materials. } \\
\text { Dominant mechanical recycling processes in industry recovers low- } \\
\text { quality materials. }\end{array}$ & $\begin{array}{l}\text { Not possible to re-use solar cells as } \\
\text { they cannot be recovered in-tact due } \\
\text { to lamination of encapsulants and } \\
\text { glasses/back sheet. }\end{array}$ & $\begin{array}{l}\text { Not possible to repair solar } \\
\text { cells. }\end{array}$ \\
\hline $\begin{array}{l}\text { Lack of } \\
\text { traceability of } \\
\text { panels and their } \\
\text { materials }\end{array}$ & $\begin{array}{l}\text { Recycling companies cannot assess the possibility of different EoL } \\
\text { processes based on panel materials and components due to a non- } \\
\text { existent database about panels. } \\
\text { Difficult to make decisions about recycling facility establishment due } \\
\text { to lack of information about panels and their compositions in specific } \\
\text { regions/countries. }\end{array}$ & $\begin{array}{l}\text { Difficult to evaluate solar panel re- } \\
\text { usability potential due to lack of } \\
\text { availability of information related } \\
\text { to panel materials, components, } \\
\text { technology, etc., which could allow } \\
\text { evaluating its second-usage value, } \\
\text { applications, and markets. }\end{array}$ & $\begin{array}{l}\text { Lack of easily accessible } \\
\text { information that would allow } \\
\text { better } \\
\text { repairability/refurbishment } \\
\text { (manufacturer } \\
\text { recommendations on } \\
\text { repairing, components } \\
\text { specifics, etc.). }\end{array}$ \\
\hline $\begin{array}{l}\text { Diversity of } \\
\text { panels } \\
\text { components and } \\
\text { materials }\end{array}$ & $\begin{array}{l}\text { Panel manufacturers introducing recyclable components or less toxic } \\
\text { materials provides additional challenges for recycling companies to } \\
\text { adapt their processes and adjust recovered materials management. }\end{array}$ & \multirow{3}{*}{$\begin{array}{l}\text { Different materials and components } \\
\text { combinations require evaluation for } \\
\text { second-hand markets (toxic } \\
\text { materials content compatibility with } \\
\text { local country, availability to recycle } \\
\text { such panels in the country, etc.). }\end{array}$} & \multirow[t]{3}{*}{$\begin{array}{l}\text { Different repairability } \\
\text { feasibility based on panels } \\
\text { composition. }\end{array}$} \\
\hline $\begin{array}{l}\text { Diversity of } \\
\text { panels sizes }\end{array}$ & $\begin{array}{l}\text { Different panels dimensions and weights influence logistics and } \\
\text { recycling machinery line feasibility to recycle them. }\end{array}$ & & \\
\hline $\begin{array}{l}\text { Diversity of } \\
\text { panels }\end{array}$ & $\begin{array}{l}\text { Glass/glass, glass/back sheet, thin films, and silicon panels can have } \\
\text { different dedicated recycling processes. Future different types of panels } \\
\text { could challenge recycling feasibility for high-value materials recovery. }\end{array}$ & & \\
\hline
\end{tabular}

Source: made by the authors 
The table provides the need to consider changes in the current panel design to allow better recyclability, repairability, reusability, and refurbishment. The sandwich structure of the panels challenges all of the circular strategies implementations. Lack of traceability of panels and their materials could allow better decision-making at choosing the most suitable path for their EoL management. Diversity of panels (there are over 105000 different panels in the world (Photovoltaikforum, 2021)) their sizes, components, and materials hinder the potential for recycling, re-use, and repair due to the complexity. In the next section analysis of the potential panel design changes will be explored.

\subsection{Selection and rating of the design changes based on their impact on circular strategies}

Table 3 compares design changes based on recycling, re-use, repair, and refurbishment, required capital investment for a manufacturer, and change in solar panel bill of materials (BOM). Each of the criteria is based on impact (low-medium-high). For recycling, re-use, and repair and refurbishment "high" impact mean that the impact is supporting significantly recycling, re-use, and repair. For required capital investment (for the manufacturer) and change in solar panel BOM, a "high" score means high costs increase. An increase in BOM costs and required capital costs are factors that have a high impact on solar panels manufacturing capability to implement the design change. As the solar industry is highly competitive it is important to take those two economic factors into account.

Table 3. Comparison of design changes (source: made by the authors)

\begin{tabular}{|c|c|c|c|c|c|c|}
\hline & $\begin{array}{l}\text { Potential for } \\
\text { Recycling }\end{array}$ & $\begin{array}{l}\text { Potential for } \\
\text { Re-use }\end{array}$ & $\begin{array}{l}\text { Potential for } \\
\text { Repair and } \\
\text { Refurbishment }\end{array}$ & $\begin{array}{l}\text { Required capital } \\
\text { investment for the } \\
\text { manufacturer }\end{array}$ & $\begin{array}{l}\text { Change in } \\
\text { solar panel } \\
\text { BOM }\end{array}$ & $\begin{array}{l}\text { Overall } \\
\text { positive impact } \\
\text { towards } \\
\text { circularity }\end{array}$ \\
\hline $\begin{array}{l}\text { N.I.C.E } \\
\text { encapsulation }\end{array}$ & High & High & High & High & Low & High \\
\hline ECA & Low & medium & Low & Medium & Medium & Medium \\
\hline Lead-free ribbons & Low & medium & Low & Low & Low & Medium \\
\hline $\begin{array}{l}\text { Fluorine-free back } \\
\text { sheet }\end{array}$ & Medium & medium & Low & Low & Medium & Medium \\
\hline RFID & $\begin{array}{l}\text { Medium- } \\
\text { High }\end{array}$ & High & High & Medium & Low & High \\
\hline
\end{tabular}

Source: made by the authors

N.I.C.E encapsulation allows a simplified recycling process with the potential to enhance repairability, reusability, or refurbishment as it allows access to solar cell replacement, which is not possible with conventional panels as they consist of plastic encapsulations. The production equipment is still under development and it would require high investment to enable this design change to be used for solar panels manufacturers.

ECA allows to designs out lead but it requires different machinery in the manufacturer production line to apply it. ECAs also usually contain silver which affects negatively the BOM cost structure and environmental impact. By designing out lead panels with ECA could be more favorable for second-hand use where solar panel application region or country lacks EoL management infrastructure.

Lead-free ribbons allow safer handling of PV waste which could be happening in regions with not yet developed recycling facilities. The performance impact is still unclear as lead-free ribbons usually have lower performance compared to lead ribbons. For this reason climate chamber tests were carried out to test lead-free ribbons with bismuth as a replacement (ribbons bought from Luvata company). The ribbons were tested in 300 hours of thermal cycles (TC) according to IEC61215 ( 3 hours per cycle between $-40{ }^{\circ} \mathrm{C}$ and $85{ }^{\circ} \mathrm{C}$ ). Table 4 shows the results of the tests. Even with the additional 100 hours of thermal cycles (200 are recommended) the 
decrease in power is less than 5\%. Ribbons with bismuth have about $1 \mathrm{~N} \mathrm{~mm}-1$ adhesion strength based on Solitek tests and literature (Geipel et al. 2019) while ribbons with lead has usually 2-3 N mm-1. EL pictures before and after 300 hours of thermal cycling (see fig. 3) show some strips having less optimal contact which are small enough issues to keep power loss within the 5\% limit of the standard. Inside one of the mini-panel NFC tag was in-laminated. NFC tags are part of RFID technologies. The main difference for NFC tags compared to other RFID tags are that they can be read with a phone and has a close reading distance. The NFC tag after the TC and damp heat $(\mathrm{DH})$ cycles were still operating as the data could be read by scanning it with the phone.

Table 4. Mini-panels with lead-free ribbons after 300 hours of thermal cycling

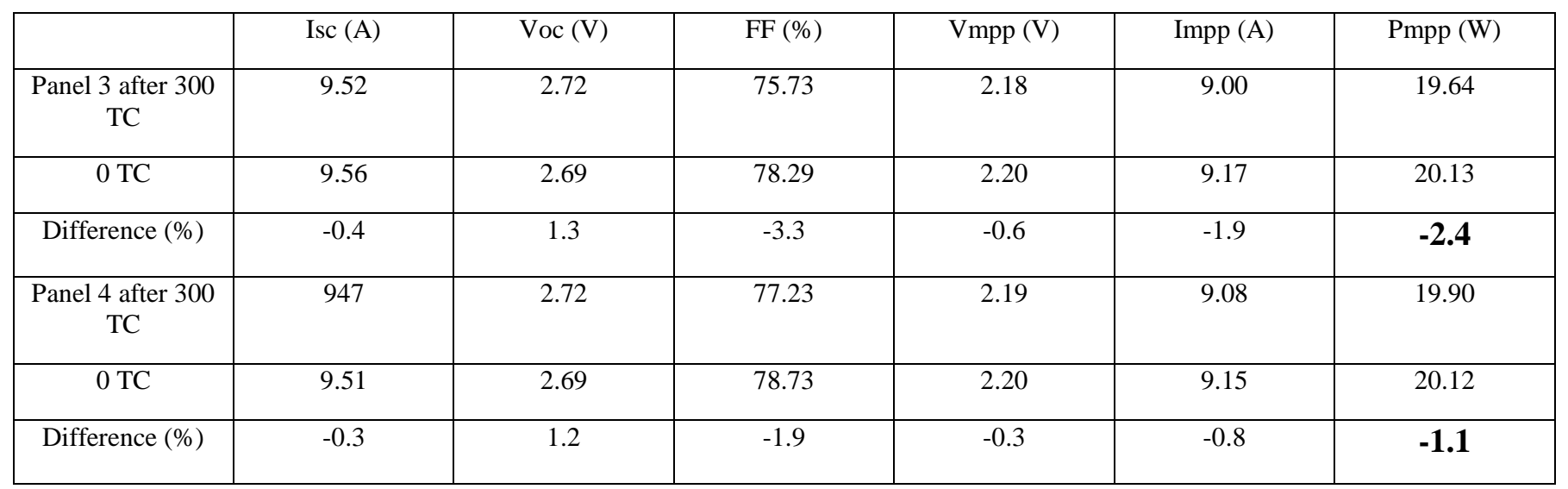

Source: made by the authors



Fig. 3. Mini-panels with lead-free ribbons before and after 300 hours of TC"

Source: made by the authors 
Fluorine-free back sheets enables less toxic gas generation during recycling. In addition, non-fluorinated recovered materials have higher quality. Fluorine-free solar panels possess fewer environmental and health risks if these types of panels are shipped abroad. After 4000 hours of DH testing of the fluorine-free back sheet (DSM endurance back sheet) in two mini-panels, there were no signs of embrittlement, cracks, internal delamination, or delamination.

RFID technology is based on information storage and ease of access. Recycling companies can access materials content of the solar panels. For re-usability purposes, RFID tags can allow transition from first to second-hand use by adding or accessing relevant information for decision makings: history of the panel, material content/toxicity, etc. It can allow effective decision makings to whether a specific type of panels should be reused outside Europe (if they have low toxicity) or be kept for second-hand applications in the EU (if they contain high-value materials such as antimony, high amount of silver, etc.). The performance history data could allow precise valuation of each of the panels for second-hand applications. Impact on recycling could be medium or high depending on the information scale (precise material content, performance history, etc.). For repair and refurbishment, RFID tags can allow storage of information about made changes and allow additional information to be written. It requires relatively medium investment costs which consist of scanners in the solar panel production line. Additional costs are for installers and recyclers if UHF RFID tags were to be used as they require dedicated readers to read and write information in the tags. From 0,30 Eur to 1 Eur RFID UHF (Ultra-high frequency) tags prices increase slightly panels costs. RFID UHF (ultra-high frequency) and NFC tags were tested in climate chambers on mini-panels. RFID UHF tags went through 4000 hours of damp heat and 200 hours of thermal cycling. 2 out of 3 attached tags were deformed after cycles (see fig. 4). The non-deformed tag (on the left side) is Alien H3, M4QT RFID UHF tag. Even though 2 out of 3 tags were deformed it was still possible to read data from the tags. One tag had silicone adhesive instead of the adhesive that is available on the side of the tag. Silicone adhesive was enough to keep the tag attached to the panel.

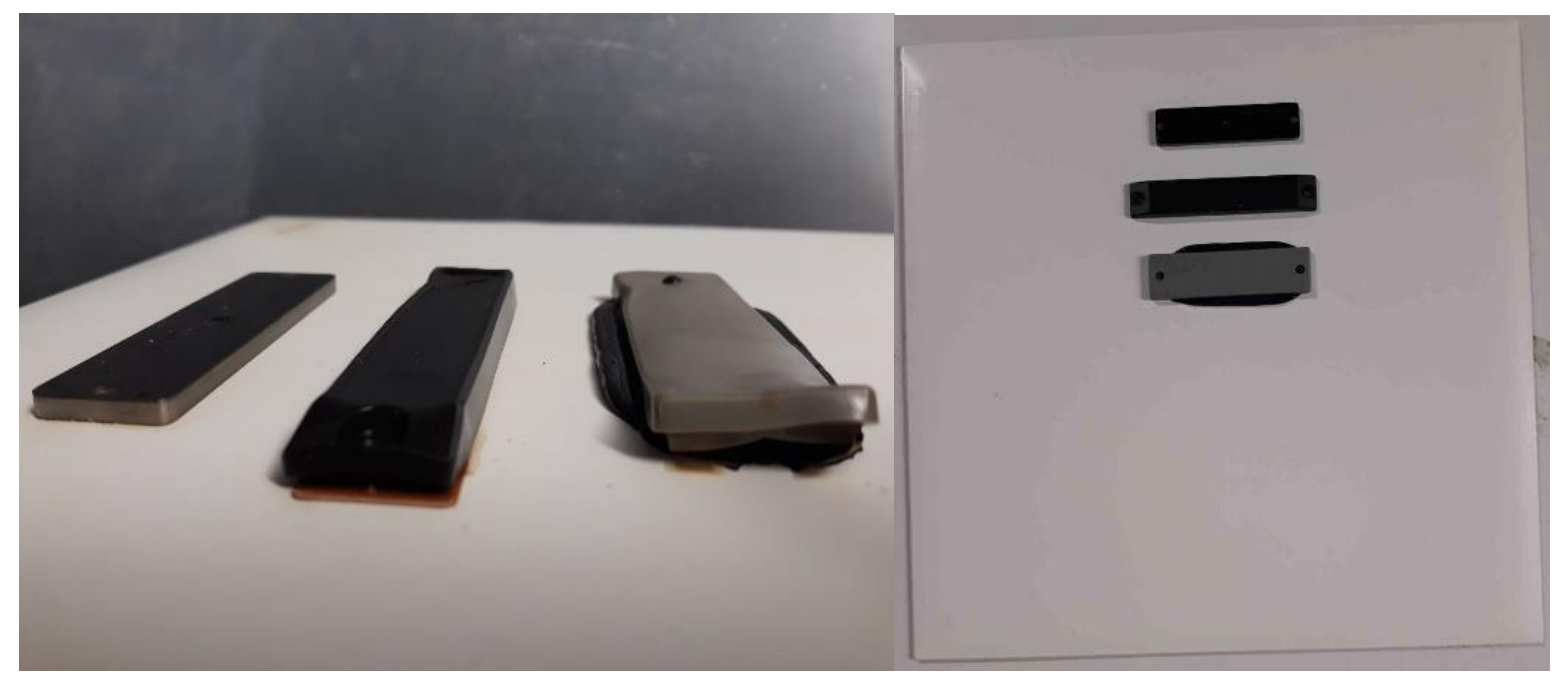

Fig. 4. RFID UHF tags after 200 hours of thermal cycling (right) and after 4000 hours of damp heat testing (left) Source: made by the authors 


\section{INSIGHTS INTO REGIONAL DEVELOPMENT}

ISSN 2669-0195 (online) http://jssidoi.org/jesi/

2021 Volume 3 Number 3 (September)

http://doi.org/10.9770/IRD.2021.3.3(1)

\subsection{Evaluation of the design changes}

One of the highest positive impacts on product circularity in terms of recycling (see table 3) would be N.I.C.E design change assuming that performance or longevity are not affected by their panel design. RFID tags can make the industry more circular through digitisation that allows enhanced information storage and ease of access. It is important to note that RFID tags require a database where information could be stored and accessed. There is a database that holds (although only in the German language) technical data of the panels, such as Power (wats), efficiency, voltage, and the number of cells per panel (Photovoltaikforum, 2021). For circular strategies improvement in the industry additional information should be stored, such as material content, repairability \& recyclability guidelines, etc. Storing data only in the tags themselves, without a database, would limit circularity opportunities as its reachability of the data would be only from close physical distance. For the solar industry, the database should be constructed and maintained in a way that it takes into account scenarios of companies (including manufacturers) ceasing to exist or other factors that can lead to disturbance of the database. The data about panels in the database should be kept and be accessible even after manufacturing companies are not operating anymore. Format of data is also important because of the panels longevity ( 30 years) there will be a significant amount of storage required that could be costly to maintain. Other design changes allow the designing of toxic materials that can result in easier EoL treatment.

To understand these potential design changes on economics, environment, and materials supply availability scenario models will be made. Three types of scenarios are based on the adoption of the design changes in the annual PV production shares $(20 \%, 50 \%, 100 \%)$.

\subsubsection{Lead-free ribbons}

Replacement of lead with another critical raw material bismuth (although non-toxic) can put additional pressure on its supply availability. Bismuth crustal abundance is $0,18(\mathrm{ppm})$, recycling rate <10\%, production concentration of $42 \%$ in China, Mexico, and Japan (The Royal Society of Chemistry, n.d.). Most of the bismuth produced today is a by-product of refining lead, copper, tin, silver, and gold ores which results in the same/similar $\mathrm{CO} 2$ impact as the lead. Its competitor lead has a crustal abundance of $11(\mathrm{ppm})$, a recycling rate of $>30 \%$, production concentration of $44 \%$ in China, Australia, and the USA (The Royal Society of Chemistry, n.d.). Bismuth worldwide production in 2018 was 19200 metric tones compared to 5560000 metric tones of lead (Merrill, 2021). Assuming 9g of bismuth consumption per panel and taking into account the world total PV manufacturing capacity of $140 \mathrm{GW}$ in 2019 (only $3 \mathrm{GW}$ manufacturing capacity in EU) the required annual supply of bismuth would be around 2400 metric tons with the assumption of the average panel having $400 \mathrm{Wp}$ (Jäger-Waldau, 2019; Statista, 2021). As bismuth concentration in the ribbons is very similar to lead the bismuth presence in each panel can be up to 9-10 grams. The average price of the past 5 years for bismuth and lead was 5776 Eur/mt and 1856 Eur/mt respectively (Shanghai Metals Market, 2021; tradingeconomics, 2021). Figure 5 shows the required bismuth amount in metric tons for different scenarios. Current low production of bismuth could lead to about $17 \%$ of its annual availability to be supplied to the solar industry if all solar panels would contain ribbons with bismuth. Combined with its higher price and currently lower recyclability compared to lead the ribbons with bismuth could limit the scalability. 
INSIGHTS INTO REGIONAL DEVELOPMENT

ISSN 2669-0195 (online) http://jssidoi.org/jesi/ 2021 Volume 3 Number 3 (September) http://doi.org/10.9770/IRD.2021.3.3(1)

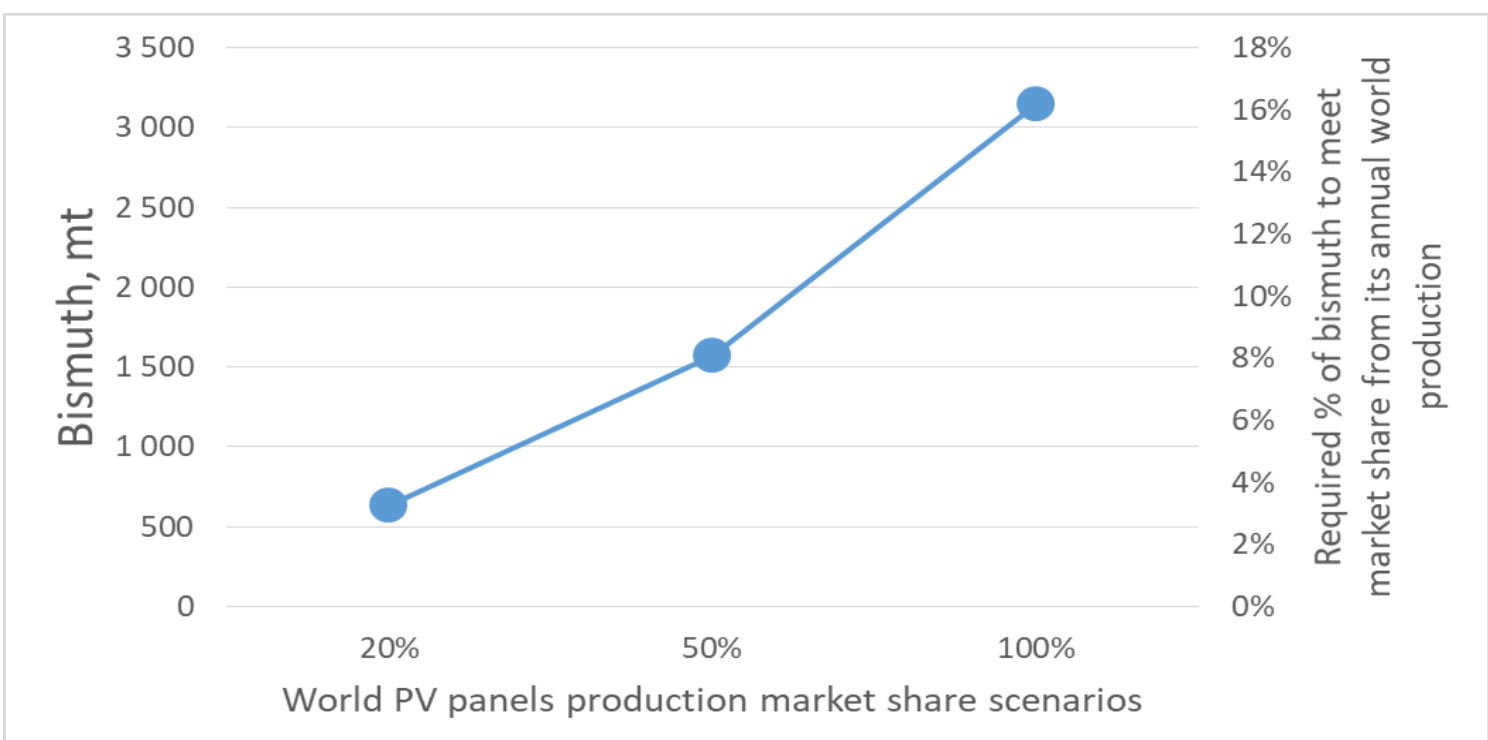

Fig. 5. Required bismuth amount and its supply availability to meet 20\%, 50\%, and 100\% PV panels production market share scenarios

\subsubsection{ECA}

Source: made by the authors

The use of ECA in the panels allows designing out lead. Figure 6 shows a reduction of lead in metric tons and the required supply of ECA in GW (140 GW annual PV panels world production) for different scenarios. It is assumed that each panel contains $9 \mathrm{~g}$ of lead and on average one panel has $400 \mathrm{Wp}$. Only about $5 \%$ of total panels in the world (2021) contain conductive adhesives (ITRPV, 2021). It is expected that conductive adhesives will reach $20 \%$ by 2021 , for this reason, the figure was adjusted accordingly to take into account only $20 \%$ of the solar panels market.

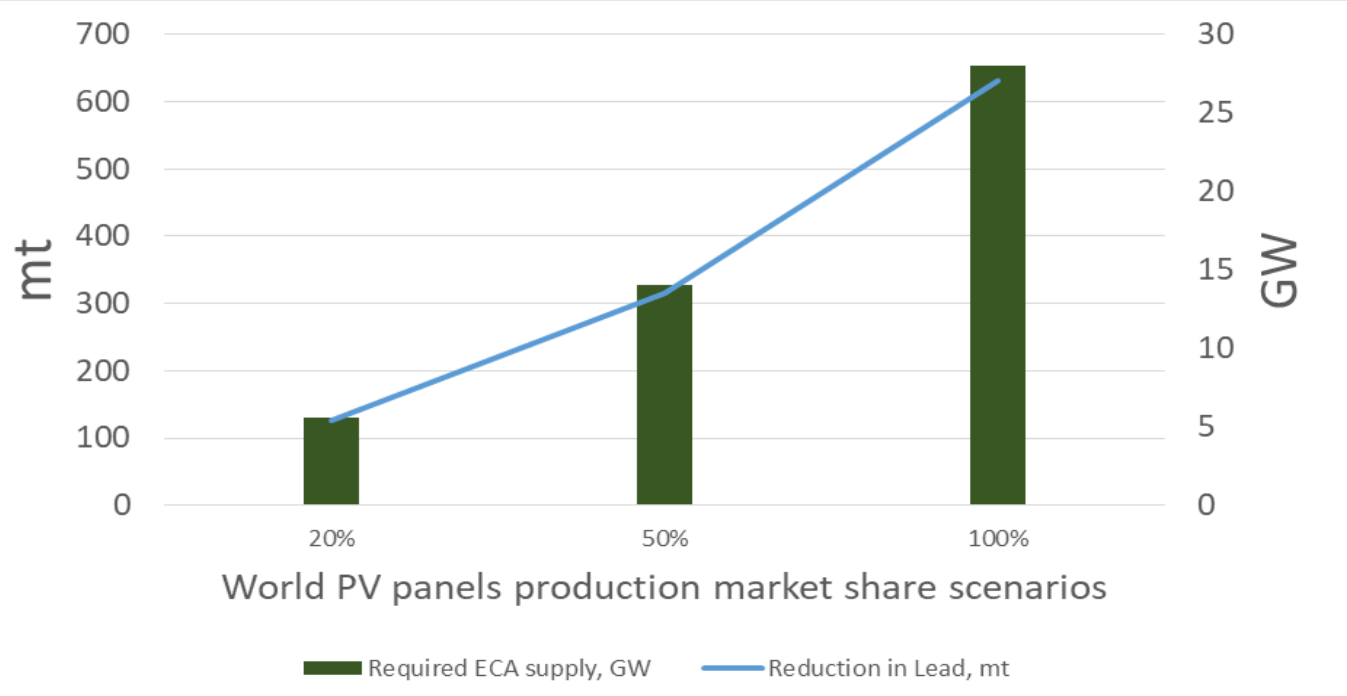

Fig. 6. Reduction of lead and required ECA supply to meet 20\%, 50\%, and 100\% PV panels production market share scenarios

Source: made by the authors 
ECA allows reducing lead consumption of the solar industry. The application of ECA depends on the solar panel technology and production line. As the ribbons stringing machine is not suitable for ECA the scalability of ECA for a higher market of solar panels would require investment into adapting the manufacturing line.

\subsubsection{NFC tags}

NFC tags price varies based on quantity, data storage capacity, and reading distance from around 0.10 Eur/peace to 0.30 Eur/peace (Made-in-China.Com, 2021). To demonstrate scenarios of NFC usage in solar panels it is assumed that from the annual world panels production of $140 \mathrm{GW}$ panels there are 350 million panels produced (400 Wp per panel). NFC tag price is assumed to be 0.30 Eur/peace. Figure 7 shows the required quantity and costs impact of NFC tags for different scenarios. The possible maintenance costs of the database are unclear. Based on the Solitek experience fixed installation costs for $\sim 100 \mathrm{MW}$ panels production capacity are around 30000 Eur.

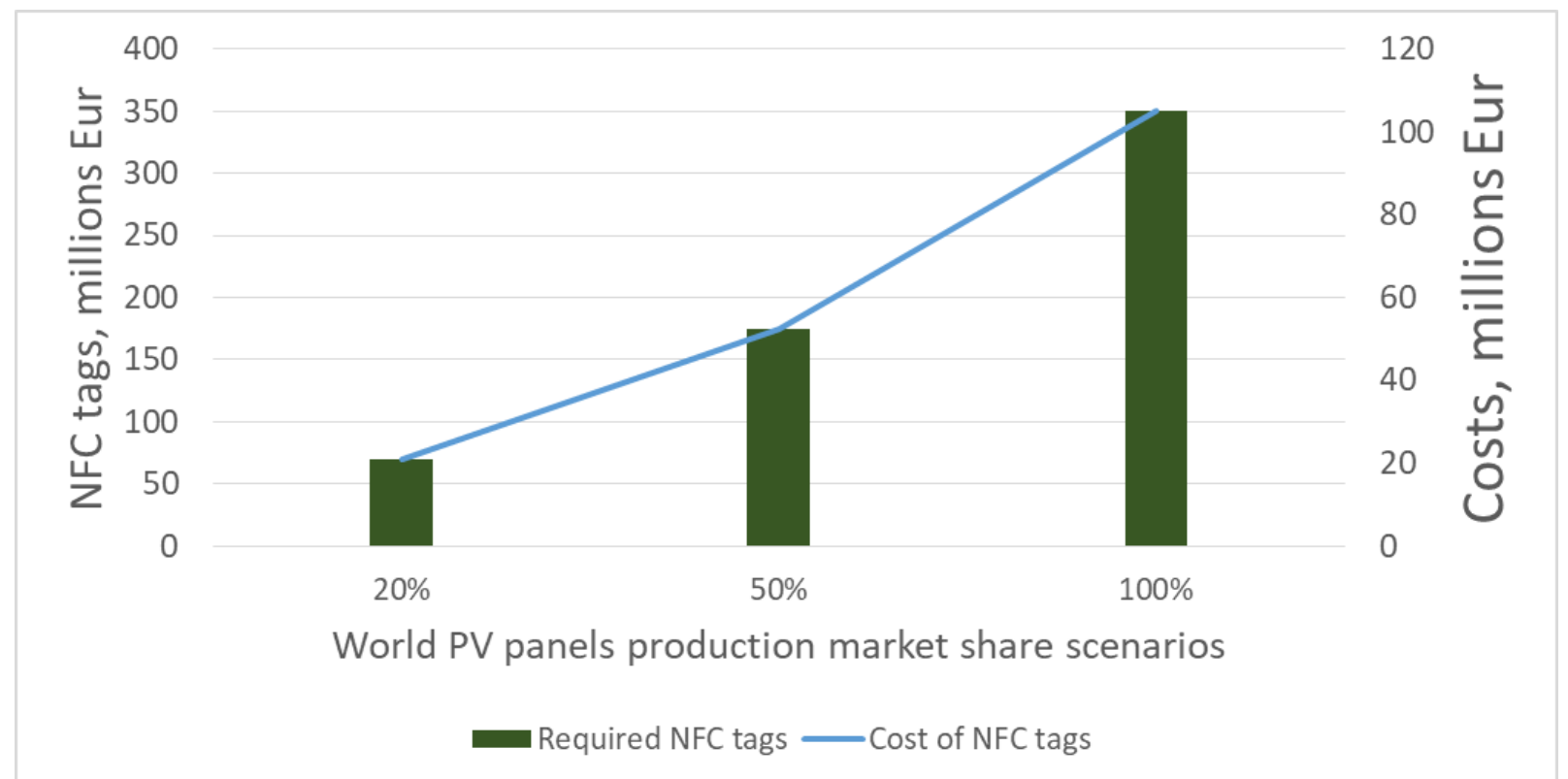

Fig. 7. Required amount of NFC tags and their costs to meet 20\%, 50\%, and 100\% PV panels production market share scenarios

Source: made by the authors

The NFC tags costs will be a relatively minor issue as the panels power is increasing significantly through the years. High power panels with high longevity are a good match for technology such as NFC tags to allow digitalised panels.

\subsubsection{Fluorine-free back sheets}

In 2021 it is expected that glass-back sheet panels will contain $80 \%$ of the panels market (ITRPV, 2021). Figure 8 shows the required supply of fluorine-free back sheets to meet different demand scenarios of panels production. The price difference is unclear for the back sheet compared to conventional ones. 


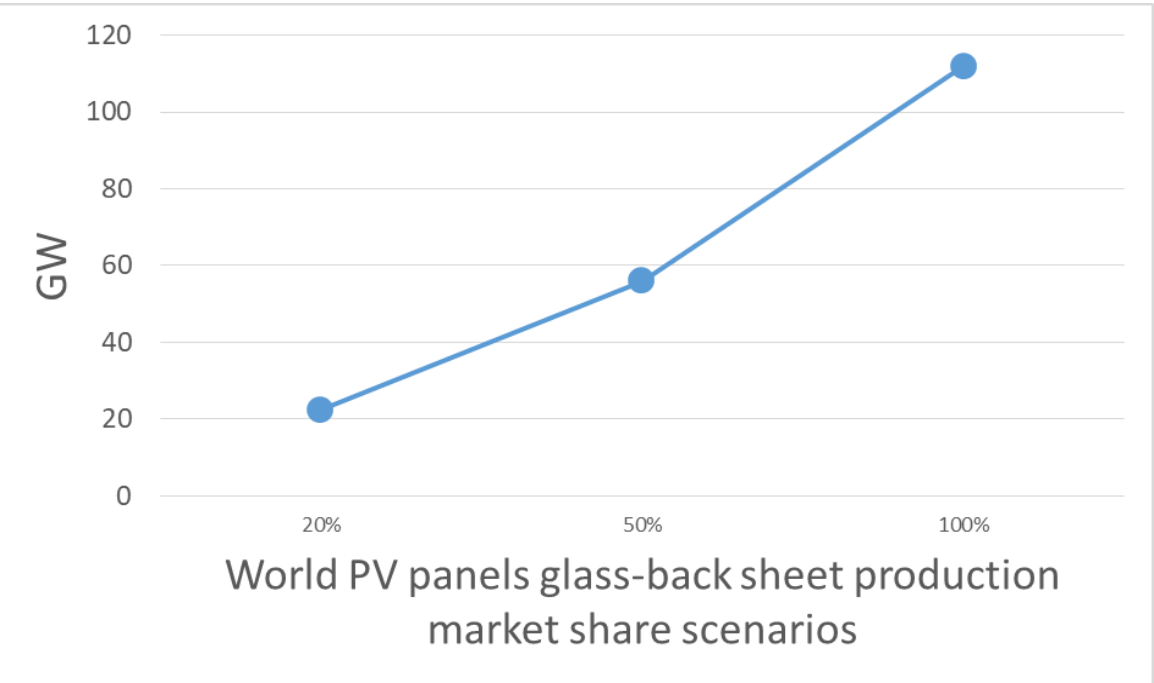

Fig. 8. Required fluorine-free back sheet supply to meet 20\%, 50\%, and $100 \%$ PV panels production market share scenarios Source: made by the authors

The back sheet market is moving away from back sheets that are based on Tedlar material. Those types of back sheets can increase recycling costs significantly due to the need for incineration. Fluorine-free back sheet or other types of back sheets (based on PET) can allow higher circularity. There is required more investigation for other types of back sheets to consider their longevity and performance impact on the panels.

\subsubsection{N.I.C.E}

Solar panel contains nitrogen gas (replacement for encapsulation material) which has a high abundance in the world. With N.I.C.E it is possible to achieve a reduction of panel price by $1.8 \%$ (Eco-solar, 2018). N.I.C.E as well designs out plastic encapsulations (EVA/POE) that has about $7 \%$ of mass present in the panel. Figure 9 shows a decrease in costs and plastic for different scenarios. It was assumed that one panel weights $20 \mathrm{~kg}$ with (350 million panels produced annually in the world). The costs reduction was calculated from the high-efficient panels that cost around 0,30 Eur/Wp (Eco-solar, 2018).

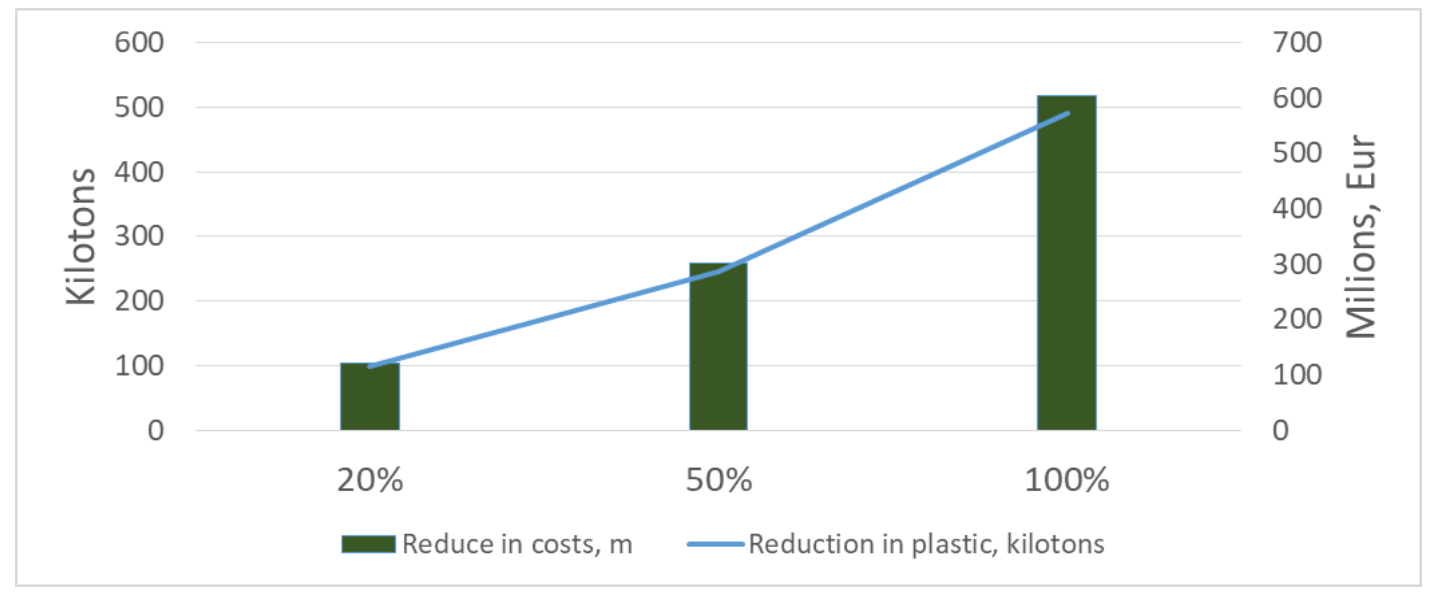

Fig. 9. Reduction of plastic and costs for $20 \%, 50 \%$, and $100 \%$ PV panels market share scenarios Source: made by the authors 


\section{INSIGHTS INTO REGIONAL DEVELOPMENT}

ISSN 2669-0195 (online) http://jssidoi.org/jesi/

2021 Volume 3 Number 3 (September)

http://doi.org/10.9770/IRD.2021.3.3(1)

The scalability of N.I.C.E technology heavily depends on Apollon company strategy related to commercialising the new encapsulation production equipment. Performance, reliability, and other tests of panels made with N.I.C.E are further required to consider the application of the design change at an industrial scale.

Each of the design changes impact on scalability through different scenarios was discussed. The supply potential of bismuth could hinder the option for promoting lead-free ribbons with bismuth as a replacement. This analysis of scalability allows to visualise the possible threats and opportunities for the design changes when considering shifting the industry towards different design changes to promote circularity.

\section{Limitations}

The literature review about the possible design changes of the panels could be broader to include low TRL (technology readiness level) designs and include other technologies besides silicon-based panels. The life-cycle analysis (LCA) approach could be used to make sure there are no trade-offs when looking at a broader picture (global warming potential, pollution, etc.). Nevertheless, the approach used in this article was to include a low amount of sensitive information to present and discuss possible design changes to be used by the solar industry companies and/or analysed further. If the data from the LCA were extracted and used from the solar industry organisations this would increase time, costs, and data complexity which would limit the potential for collaboration between the companies.

A broader discussion of the design issues and possible design changes could be done by including components suppliers into providing inputs and/or participating in the workshop that was organised within the CIRCUSOL project. The possible design changes and their impacts on the component producers are important to have a wider understanding of possible improvements of the product parts. For the increase of circularity of materials and components the producers feedback is crucial to discuss the challenges and opportunities of returning recycled materials to the producers. Future research areas could apply/adapt the 4 steps approach of product circularity improvement in other industries by taking into account policies, business models, reverse logistics, etc. The product technological design is one of the most important first steps to improve circularity. Nevertheless, other circularity aspects could also be addressed in future researches (take-back procedures, recovered materials applications, circular business models) while focusing on collaboration between relevant organisations to generate solutions.

\section{Conclusions}

Literature review shows the need for the circular supply chains to redesign the products for improving reparability, recyclability, etc. Technological design changes at the product level required an understanding of the context of the supply chain that is related to technology, economy, environment, etc. There is a lack of investigation about the simple methods and processes to identify circularity of product, its impact on circular strategies, and relating possible design changes to the impact not only based on the manufacturer but further supply chain as well. This article investigated at the industry level possible design changes of the solar panel and their impacts.

Process steps for improving product circularity were proposed based on literature. It consists of the identification of product circularity issues, their impact on circularity, possible design changes to improve the circularity and their impact on the whole supply chain, and evaluation of those design changes. It is a 4 steps approach that allows a simple way to identify circularity issues, investigate potential design changes based on circular strategies, rate the design changes and evaluate their impacts. The combination of literature data and expert inputs allows higher freedom of collaboration between the supply chain organisations as it contains much less sensitive data compared to traditional eco-design approaches.

The main issue of the solar panel is the sandwich structure that blocks easy recycling and other circular strategies implementation. Other issues are related to the presence of toxic materials in the solar panel and lack of relevant information accessibility about the panel during its lifetime. Additional design issue of different 


\section{INSIGHTS INTO REGIONAL DEVELOPMENT}

ISSN 2669-0195 (online) http://jssidoi.org/jesi/

2021 Volume 3 Number 3 (September)

http://doi.org/10.9770/IRD.2021.3.3(1)

dimensions of the panels was revealed in the online workshop dedicated to discussing the solar panel design issues.

After identification of design issues of the solar panel their impacts on the relevant circular strategies in the solar industry (recycle, re-use, repair/refurbishment) were discussed. The following design changes of the solar panel were selected to improve the recyclability, re-usability, and repairability/refurbishment: RFID technology, lead-free ribbons, ECA, fluorine-free back sheet, and N.I.C.E. These design changes impact differently manufacturer and further supply chain actors through circular strategies.

The most impactful design changes for higher circularity of the product are N.I.C.E and RFID technology. These two design changes have a very different cost impact on the manufacturer. Depending on the manufacturer and its value chain one or another design change could be chosen. Except for the N.I.C.E and ECA, other design changes do not require high investment costs for a manufacturer to allow more circular solar panel design. A low amount of design changes costs allows small \& medium manufacturers to implement the design changes.

Evaluated possible design changes for circularity through literature review and inputs provided by the experts from the industry combined with considerations for scalability presents insights for solar industry companies to adopt circular design changes. The used methodology based on low sensitive data allowed collaboration within the supply chain to investigate circularity improvement in the solar industry through product design.

\section{References}

Acerbi, F., \& Taisch, M. (2020). A literature review on circular economy adoption in the manufacturing sector. In Journal of Cleaner Production (Vol. 273, p. 123086). Elsevier Ltd. https://doi.org/10.1016/j.jclepro.2020.123086

Alamerew, Y. A., Kambanou, M. L., Sakao, T., \& Brissaud, D. (2020). A multi-criteria evaluation method of product-level circularity strategies. Sustainability (Switzerland), 12(12), 5129. https://doi.org/10.3390/su12125129

Bris, H. Saint. (2016). Balancing demand and supply for secondary raw materials.

Cannella, S., Ponte, B., Dominguez, R., \& Framinan, J. M. (2021). Proportional order-up-to policies for closed-loop supply chains: the dynamic effects of inventory controllers Proportional order-up-to policies for closed-loop supply chains: the dynamic effects of inventory controllers. https://doi.org/10.1080/00207543.2020.1867924

Cucchiella, F., D’Adamo, I., \& Rosa, P. (2015). End-of-Life of used photovoltaic modules: A financial analysis. In Renewable and Sustainable Energy Reviews (Vol. 47, pp. 552-561). Elsevier Ltd. https://doi.org/10.1016/j.rser.2015.03.076

D’Adamo, I., Miliacca, M., \& Rosa, P. (2017). Economic Feasibility for Recycling of Waste Crystalline Silicon Photovoltaic Modules. International Journal of Photoenergy, 2017. https://doi.org/10.1155/2017/4184676

Eco-solar. (2018). Eco-Solar Eco-Solar Factory: 40\%plus eco-efficiency gains in the photovoltaic value chain with minimised resource and energy consumption by closed loop systems D 23 Report Final LCA and EEA.

Eco-sources. (2019). The Classification And Structure Composition Of Solar Panels | Eco-Sources. https://www.eco-sources.com/theclassification-and-structure-composition-of-solar-panels/

European Commission. (2019). The new ecodesign measures explained https://ec.europa.eu/commission/presscorner/detail/en/qanda_19_5889

Eurostat. (2020). Recycling â€" secondary material price indicator - Statistics Explained. https://ec.europa.eu/eurostat/statistics-



Fraunhofer. (2020). Photovoltaics Report. www.ise.fraunhofer.de

Geipel, T., Eberlein, D., \& Kraft, A. (2019). Lead-free solders for ribbon interconnection of crystalline silicon PERC solar cells with infrared soldering. 2156, 20015. https://doi.org/10.1063/1.5125880 


\section{INSIGHTS INTO REGIONAL DEVELOPMENT}

ISSN 2669-0195 (online) http://jssidoi.org/jesi/

2021 Volume 3 Number 3 (September)

http://doi.org/10.9770/IRD.2021.3.3(1)

Geissdoerfer, M., Pieroni, M. P. P., Pigosso, D. C. A., \& Soufani, K. (2020). Circular business models: A review. In Journal of Cleaner Production (Vol. 277). Elsevier Ltd. https://doi.org/10.1016/j.jclepro.2020.123741

Govindan, K., \& Hasanagic, M. (2018). A systematic review on drivers, barriers, and practices towards circular economy: a supply chain perspective. International Journal of Production Research, 56(1-2), 278-311. https://doi.org/10.1080/00207543.2017.1402141

Ha, T. (2020). The elephant in the room: Can the solar industry go circular? | News | Eco-Business | Asia Pacific. https://www.ecobusiness.com/news/the-elephant-in-the-room-can-the-solar-industry-go-circular/

Iacovidou, E., Hahladakis, J. N., \& Purnell, P. (2020). A systems thinking approach to understanding the challenges of achieving the circular economy. Environmental Science and Pollution Research, 1-22. https://doi.org/10.1007/s11356-020-11725-9

IEA. (2020). IEA - International Energy Agency - IEA. https://www.iea.org/data-and-statistics/data-products

ITRPV. (2021). International technology roadmap for photovoltaic (ITRPV). https://itrpv.vdma.org/documents/27094228/29066965/20210ITRPV/08ccda3a-585e-6a58-6afa-6c20e436cf41

Jäger-Waldau, A. (2019). PV Status Report 2019. Publications Office of the European Union, 85. https://ec.europa.eu/jrc/sites/jrcsh/files/kjna29938enn_1.pdf

Kopnina, H. (2018). Circular economy and Cradle to Cradle in educational practice. Journal of Integrative Environmental Sciences, 15. https://doi.org/10.1080/1943815x.2018.1471724

Kumar, P., Singh, R. K., \& Kumar, V. (2021). Managing supply chains for sustainable operations in the era of industry 4.0 and circular economy: Analysis of barriers. Resources, Conservation and Recycling, 164, 105215. https://doi.org/10.1016/j.resconrec.2020.105215

Latunussa, C., Mancini, L., Andrea, B. G., \& Fulvio, A. (2016). (PDF) Analysis of Material Recovery from Silicon Photovoltaic Panels. https://www.researchgate.net/publication/301693669_Analysis_of_Material_Recovery_from_Silicon_Photovoltaic_Panels

Luceño-Sánchez, J. A., Díez-Pascual, A. M., \& Capilla, R. P. (2019). Materials for photovoltaics: State of art and recent developments. In International Journal of Molecular Sciences (Vol. 20, Issue 4). MDPI AG. https://doi.org/10.3390/ijms20040976

Mackay, O. (2020). Why traceability matters in recycling and the circular economy. https://www.everledger.io/why-traceability-matters-inrecycling-and-the-circular-economy/

Made-in-China.com. (2021). https://www.made-in-china.com/

Maranesi, C., \& De Giovanni, P. (2020). Modern Circular Economy: Corporate Strategy, Supply Chain, and Industrial Symbiosis. Sustainability, 12(22). https://doi.org/10.3390/su12229383

Merrill, A. (2021). Bismuth statistics and information. https://www.usgs.gov/centers/nmic/bismuth-statistics-and-information

Photovoltaikforum. (2021). Photovoltaikforum. https://www.photovoltaikforum.com/

Rossi, M., Germani, M., \& Zamagni, A. (2016). Review of ecodesign methods and tools. Barriers and strategies for an effective implementation in industrial companies. Journal of Cleaner Production, 129, 361-373. https://doi.org/10.1016/J.JCLEPRO.2016.04.051

Sanyé-Mengual, E., Lozano, R. G., Farreny, R., Oliver-Solà, J., Gasol, C. M., \& Rieradevall, J. (2014). Introduction to the Eco-Design Methodology and the Role of Product Carbon Footprint. 1-24. https://doi.org/10.1007/978-981-4560-41-2_1

Shanghai Metals Market. (2021). Refined Bismuth today . https://www.metal.com/Bismuth-Selenium-Tellurium/201102250578

Shellenberger, M. (2018). If Solar Panels Are So Clean, Why Do They Produce So Much Toxic Waste? https://www.forbes.com/sites/michaelshellenberger/2018/05/23/if-solar-panels-are-so-clean-why-do-they-produce-so-much-toxicwaste/?sh=309dde90121c

Singh, J., Sung, K., Cooper, T., West, K., \& Mont, O. (2019). Challenges and opportunities for scaling up upcycling businesses - The case of textile and wood upcycling businesses in the UK. Resources, Conservation and Recycling, 150, 104439. 
https://doi.org/10.1016/j.resconrec.2019.104439

Statista. (n.d.). • Regional distribution of solar PV cells production | Statista. 2018. Retrieved June 8, 2021, from https://www.statista.com/statistics/268682/regional-distribution-of-solar-cell-manufacturing/

Statista. (2021). Annual solar module production worldwide . https://www.statista.com/statistics/668764/annual-solar-modulemanufacturing-globally/

Swarc, J. (n.d.). Solar Panel Construction - Clean Energy Reviews. 2020. Retrieved June 8, 2021, from https://www.cleanenergyreviews.info/blog/solar-panel-components-construction

Tao, M., Fthenakis, V., Ebin, B., Steenari, B. M., Butler, E., Sinha, P., Corkish, R., Wambach, K., \& Simon, E. S. (2020). Major challenges and opportunities in silicon solar module recycling. Progress in Photovoltaics: Research and Applications, 28(10), 1077-1088. https://doi.org/10.1002/pip.3316

The Royal Society of Chemistry (n.d.). Retrieved July 14, 2021, from https://www.rsc.org/

tradingeconomics. (2021). Lead | 1993-2021 Data |2022-2023 Forecast $\mid$ Price $\mid$ Quote $\mid$ Chart $\mid$ Historical $\mid$ News. https://tradingeconomics.com/commodity/lead

Veolia. (n.d.). Homepage | Veolia. 2020. Retrieved May 26, 2021, from https://www.veolia.com/en

\section{Funding}

The authors acknowledge the valuable contribution of all project partners within CIRCUSOL (call: H2O2 0-EU.3.5.4). This project has received funding from the European Union's Horizon 2020 research and innovation programme under grant agreement 776680.
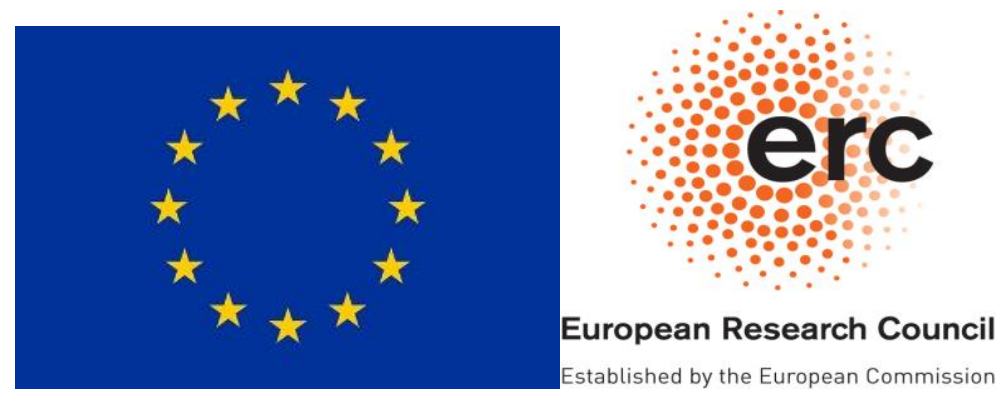
INSIGHTS INTO REGIONAL DEVELOPMENT

ISSN 2669-0195 (online) http://jssidoi.org/jesi/ 2021 Volume 3 Number 3 (September)

http://doi.org/10.9770/IRD.2021.3.3(1)

Tadas RADAVICIUS

ORCID ID: https://orcid.org/0000-0002-5222-7499

Arvid van der HEIDE

ORCID ID: https://orcid.org/0000-0002-7589-4526

Wolfram PALITZSCH

ORCID ID: https://orcid.org/0000-0002-5780-1322

Tom ROMMENS

ORCID ID: https://orcid.org/0000-0002-5952-5288

Julius DENAFAS

ORCID ID: https://orcid.org/0000-0002-4698-9403

Manuela TVARONAVIČIENÉ

ORCID ID: https://orcid.org/0000-0002-9667-3730

Make your research more visible, join the Twitter account of INSIGHTS INTO REGIONAL DEVELOPMENT:

@IntoInsights

Copyright (C) 2021 by author(s) and VsI Entrepreneurship and Sustainability Center

This work is licensed under the Creative Commons Attribution International License (CC BY).

http://creativecommons.org/licenses/by/4.0/ 